\title{
The Invention of Modern State Terrorism during the French Revolution
}

\author{
Guillaume Ansart
}

\section{Synopsis}

This essay discusses three aspects of the Terror (September 1793-July 1794): (1) The Institutions of the Terror: The Committee of General Security, the Committee of Public Safety, and the Revolutionary Tribunal; (2) the Theory of Terror: The unity and indivisibility of the people, the category of enemy of the people, and the concept of Revolution as a state of war against aristocratic/foreign conspiracies; (3) the Language of Terror: The Terror is also a performative language, a language which embodies terror by aiming to silence all debate. In this sense, the language of Terror is Terror itself.

\section{Biography}

Guillaume Ansart is Associate Professor of French at Indiana University, Bloomington. His recent research has focused on the political culture of late eighteenth-century France, especially Raynal and Diderot's Histoire des deux Indes and Condorcet, whose writings on the United States he has edited for Classiques Garnier and translated for Penn State UP (both forthcoming in 2012).

\section{Essay}

Originality of the Terror

Terror, of course, has been used throughout history by despots and tyrants of every kind. Even under what Montesquieu, in The Spirit of the Laws (1748), called "moderate" governments (e.g. ancient republics or modern monarchies), the notion that times of crisis and exceptional circumstances, when the very survival of the body politic is at stake, may sometimes require the suspension of normal legal guarantees, was commonly accepted. Ancient Rome could and did rely many times on the institution of the dictatorship; French absolutism used the concept of raison d'État. However, the Terror in revolutionary France (September 1793-July 1794) did inaugurate something new. It marks the first time a government attempted to institute a "despotism of freedom," to base a regime of terror on the universal values of liberty and equality.

The Institutions of the Terror 
The Terror would not have been possible without the power vacuum created by the fall of the monarchy in August 1792. For the next three years, France was left without a constitution, without a separate executive power, and with only a single assembly of elected representatives, the National Convention. All legal political power would have to emanate from the Convention. During the winter and spring of 1793 , a first constitution (the Girondine) was presented to the Convention but rejected, then a second, Jacobin constitution, was adopted but immediately set aside because of the institution of the revolutionary government.

The revolutionary government, responsible for the implementation of the Terror, took shape gradually over the course of 1793 . Power became concentrated in two committees of the Convention: The Committee of General Security, overseeing justice, the police and surveillance in general, and above all the Committee of Public Safety (created in April), invested with extensive executive and other powers. In Paris, a special revolutionary tribunal, under the direct control of the Convention and the two Committees, was established in March to judge expeditiously those suspected of counter-revolutionary activities or sympathies. Outside of Paris, the Convention appointed representatives to local administrations and the armies with almost unlimited powers to organize repression in conjunction with local surveillance committees. Such were the main institutions of the Terror, which the Convention declared "the order of the day" on September 5 . The revolutionary government itself was officially proclaimed on October 10 and further codified on December 4. Two of the most famous, or infamous, laws from this period were the Law of Suspects (September 17, 1793), which called for the arrest of all "those who, by their conduct, associations, comments, or writings have shown themselves partisans of tyranny or federalism and enemies of liberty," and the law of 22 Prairial Year II (June 10, 1794), marking the culmination of the Terror, which broadened the notion of "enemy of the people" to such an extent that every citizen critical of the government could potentially be included in that category and which radically streamlined the already summary procedures of the Revolutionary Tribunal, eliminating the preliminary examination of the accused and the right to a defense counsel.

\section{The Theory of Terror}

One of the most common interpretations of the Terror, especially among left-leaning historians, has been to explain it as a response to external circumstances. Indeed, 1793 was a grim year for the French Republic: The threat of foreign invasion, counterrevolutionary activity in the provinces-particularly the civil war in Vendée-, serious economic difficulties, all contributed to a sense that the Revolution was in danger and that exceptional measures were needed to save it. Another factor often invoked is the increasing pressure exercised on the Convention by the Parisian peuple and the sansculotte activists. Here, the role of spontaneous popular violence is brought to the fore.

Without denying the importance of these factors, other, for the most part more recent interpreters of the Revolution, have insisted on the inner logic of the Terror. ${ }^{1}$ From a theoretical standpoint, the Terror rests on a few basic assumptions regarding the people and its sovereignty. The peuple is inherently good. It is at one with itself and knows no internal divisions (Manin 190-201). Therefore, the collective will of the people, 
the only legitimate source of political power, is also one and indivisible. Moreover, the Jacobins conceived the axiom of the sovereignty of the people in absolute terms, on the model of Rousseau's Social Contract (1762). But the principle of the unity and absolute sovereignty of the people had to be reconciled with the necessity, in a large modern nation, of political representation. Essentially, the Jacobins attempted to solve this basic contradiction between representation and direct democracy with a political fantasy: The Convention did not simply represent the people, it was the people (Manin 171-78). Thus, Robespierre, for instance, established his position of power as the voice of the people through a series of sweeping identifications: His power emanated from the Committee of Public Safety, which was itself an emanation of the Convention, whose power he, Robespierre, identified with the will of the people; consequently, his voice was none other than the people's voice (Lefort 64). "It is the inevitable paradox of direct democracy that it replaces electoral representation with a system of abstract equivalences in which the people's will always coincides with power and in which political action is exactly identical with its legitimacy" (Furet, Interpreting the Revolution 48).

Again, for the advocates of Terror, there could be no divisions within the people; the only dividing line was between the people and its enemies. But since it did not exist in reality, the unity of the people had to be constantly created or recreated by eliminating dissenting groups which, by their very dissent, had placed themselves outside of the people. Hence the successive attacks against real or imagined factions and conspiracies: Louis XVI and the royalists, the Girondins, the Hébertistes, the Dantonistes... Every purge was meant to restore the fiction of the unity of the people: "The image of a society which is at one with itself and which has been delivered from its divisions can only be grasped during the administration of the purge, or, better still, during the work of extermination" (Lefort 84). ${ }^{2}$

To this fiction of perfect unity - within the people and the Convention, as well as between the two-must be added another, that of transparent immediacy. Because they could act as screens between the Convention and the people, administrations were to be continually monitored and purged (Manin 178-90). Similarly, revolutionary justice had to be almost instantaneous, requiring only the short time it takes for virtue to distinguish between friend and foe. As Robespierre famously said: "Terror is nothing but prompt, severe, inflexible justice; it is therefore an emanation of virtue; it is not so much a specific principle as a consequence of the general principle of democracy applied to the homeland's most pressing needs" (Virtue and Terror 115 [speech of February 5, 1794]); or as Couthon put it: "The time prescribed for punishing the enemies of the Fatherland must be reduced to the time it takes to recognize them; it is a matter of annihilating them rather than of punishing them" (quoted in Lefort 82). The law of 22 Prairial left only two options to the jury of the Revolutionary Tribunal, acquittal or death.

All this leads us to one of the most important conceptual categories of the theory of Terror, that of enemy of the people. It emerged in Robespierre's and Saint-Just's speeches on the trial of Louis XVI in late 1792 (Manin 206-8; Edelstein 146-58, 24953). The King, they argued, had severed the bond that united him to the nation. He could not claim the protection of positive law because he had put himself outside of civil society. In relation to each other, the nation and the King found themselves back in the state of Nature, so the monarch should be treated according to the Law of Nations [droit 
des gens] or Natural Law. The King was not a citizen to be judged but an enemy to be destroyed. Saint-Just told the Convention that "Louis XVI must be judged as a foreign enemy" (speech of November 13, 1792 82; my translation); and Robespierre agreed: "Citizens, be careful; you are being misled here by false notions. You are confusing the rules of civil and positive law with the principles of the law of nations; you are confusing relations between citizens with those between a nation and an enemy conspiring against it" (Virtue and Terror 58 [speech of December 3, 1792]; translation slightly corrected).

Once established, the category of enemy of the people could easily be extended. Saint-Just emphasized with great lucidity the importance of the King's trial for the future of the Revolution: "The spirit with which the king will be judged will be the same as that with which the Republic will be founded" (speech of November 13, 1792 81; my translation). The spirit Saint-Just hoped would prevail during the King's trial, and which did to some extent, clearly foreshadows the logic of revolutionary justice: "Tribunals are established only for the members of the city," "at the moment a man is guilty, he steps outside of the body politic" (speech of November 13, 1792 80, 81; my translation). Robespierre will offer the same argument at the height of the Terror: "Social protection is due only to peaceful citizens; there are no citizens but republicans in the Republic. Royalists and conspirators are foreign to it, or rather they are enemies" (Virtue and Terror 115 [speech of February 5, 1794]). Dissent could only be the instrument of factions which conspire to divide the people and undermine the unity of the Republic in order to destroy it. So the Terror always formulated the threats posed by the enemies of the Republic in terms of aristocratic/foreign conspiracies (Furet, Interpreting the Revolution 53-56).

The regime of Terror is thus a state of war, which makes revolutionary government quite different from normal constitutional government: "Revolution is the war of liberty against its enemies: the constitution is the system of liberty victorious and at peace. ... Revolutionary government owes good citizens full national protection; to enemies of the people it owes nothing but death" (Robespierre, Virtue and Terror 99 [speech of December 25, 1793]). A war to the death, then, between good and evil, virtue and vice, the will of the people and aristocratic conspiracies, Natural Right and the enemies of Nature. ${ }^{3}$

\section{The Language of Terror}

More than just a political theory and a simple set of institutions to put it into practice, the Terror was also a performative language, a language which embodied terror by aiming to silence all debate. In this sense, the language of Terror was Terror itself (Lefort 60).

As we have seen, the Terror assimilated dissent to treason, to conspiracies hatched by counter-revolutionary elements and foreign powers bent on dividing the people to weaken the Republic. In fact, no one was safe from the accusation of conspiracy. On the right, those who asked for a pause in the Terror were charged with modérantisme and pro-aristocratic leanings, on the left, those who preached atheism and even more radical purges were denounced for exagération and a secret desire to discredit the Revolution by their excesses. But no one could tell precisely where the truth between modérantisme and exagération lay: "What will trace the line of 
demarcation between all the contradictory excesses? Love of the homeland and truth," Robespierre answered rather tautologically (Virtue and Terror 101 [speech of December $25,1793])$. The vagueness or indeterminacy of the language of Terror was essential to its efficacy. It terrorized because no one could know for certain what it took to be considered part of the people or one of its enemies. At the same time, it helped sustain the fantasy of the unity of the people, for any attempt to give precise definitions of such categories as "the people" or "the enemies of the people" would have instantly revealed the real divisions these categories masked (Manin 204-6, 208-9). What did all the alleged enemies of the people, the royalists, the Girondins, the Hébertistes, the Dantonistes, have in common? Very little. But the language of Terror could silence competing discourses by reducing them all to their "objective" identical result, undermining the Revolution. "Judge them, not by the difference of language, but by the sameness of the results" (Robespierre, Virtue and Terror 119 [speech of February 5, 1794]).

Finally, the language of Terror reveals a tendency toward the sublime or the inhuman (Žižek $x$-xix). The birth of the Republic is likened to the mystery of an act of pure creation out of nothing: "Liberty has been established; it emerged in the midst of storms: it has this origin in common with the world, which emerged from chaos, and with man, who cries while being born" (Saint-Just, speech of April 15, 1794 258; my translation). Conversely, the Terror celebrated a cult of death and martyrdom. Revolutionaries, to be pure, must not be afraid to die. In a speech delivered to the Convention on 11 Germinal Year II (March 31, 1794), ${ }^{4}$ the day after the arrest of Danton and Camille Desmoulins, Robespierre exclaimed: "I say that anyone who trembles at this moment is guilty." To be afraid is to be guilty, not just because fear might constitute a sign of some specific guilt, but because, more essentially, it is a crime to fear the people and the Revolution. Fear is guilt, for it betrays a lack of commitment to the Revolution (Lefort 64-67; Žižek xvi-xvii). In the words of Saint-Just: "You must punish not only traitors, but even those indifferent to the Revolution; you must punish whoever remains passive within the Republic and does nothing for it" (speech of October 10, 1793 169; my translation). Robespierre, for his part, knew no fear and could still say, the day before his execution: "I promised some time ago to leave a testament that would be redoubtable to oppressors of the people. I am going to proclaim it now with the independence appropriate to the situation I am in: I bequeath them the terrible truth and death." "What can they hold against one who wants to speak the truth and consents to die for it?" (Virtue and Terror 134, 140 [speech of July 26, 1794]; translation slightly corrected).

Notes

1. See especially Furet, Interpreting the Revolution and "Terror;" Manin; and Edelstein.

2. See also Manin 202-10; Furet, "Terror" 149.

3. On the importance of Natural Right in revolutionary ideology, see Edelstein. 
4. This speech is analyzed in Lefort 59-69, and Žižek xv-xvii.

\section{Works Consulted}

Baker, Keith M. "Political Languages of the French Revolution." The Cambridge History of Eighteenth-Century Political Thought. Ed. Mark Goldie and Robert Wokler. Cambridge: Cambridge University Press, 2006. 626-59.

Edelstein, Dan. The Terror of Natural Right: Republicanism, the Cult of Nature, and the French Revolution. Chicago: University of Chicago Press, 2009.

Furet, François. Interpreting the French Revolution. Trans. Elborg Forster. Cambridge: Cambridge University Press, 1981.

- "Terror." A Critical Dictionary of the French Revolution. Ed. François Furet and Mona Ozouf. Trans. Arthur Goldhammer. Cambridge, Mass.: Harvard University Press, 1989. 137-50.

Lefort, Claude. "The Revolutionary Terror." Democracy and Political Theory. Trans. David Macey. Minneapolis: University of Minnesota Press, 1988. 59-88.

Manin, Bernard. "Saint-Just, la logique de la terreur." Libre: politique, anthropologie, philosophie. 6. Paris: Payot, 1979. 165-231.

Robespierre, Maximilien. Textes choisis. Ed. Jean Poperen. 3 vols. Paris: Éditions Sociales, 1956-58.

—. Virtue and Terror. Ed. Jean Ducange. Introd. Slavoj Žižek. Trans. John Howe. London: Verso, 2007.

Saint-Just, Louis-Antoine de. Fuvres choisies. Ed. Dionys Mascolo. Introd. Jean Gratien. Paris: Gallimard, 1968.

Žižek, Slavoj. "Robespierre, or, the 'Divine Violence' of Terror." Introduction. Virtue and Terror. By Maximilien Robespierre. Ed. Jean Ducange. Trans. John Howe. London: Verso, 2007. vii-xxxix. 